\title{
The role of Democracy in Infrastructural Development of Anambra West Local Government Area, Southeast, Nigeria \\ DOI: 10.36108/NJSA/6102/14(0250)
}

\author{
Clement Emeka Ikezue \\ Peter Chukwuma Ezeah \\ Sociology/Anthropology Department \\ Nnamdi Azikiwe University, Awka \\ E-mail: ec.ikezue@unizik.edu.ng
}

\begin{abstract}
This paper examined how the present democratic dispensation in Anambra State has contributed to the infrastructural development of Anambra West local government area, which suffered obvious neglect for a long time. This paper adopted the cross sectional survey design and selected 400 respondents using the Yamane's sample size determination formula. The paper employed both the quantitative and qualitative research methods. Results indicate that democracy could be a potent tool for development if every segment of the society is carried along in the process. The paper also found that democracy as a form of government is more likely to guarantee equitable distribution of power and resources among the constituting units of the state. It is recommended among others that politicking should be carried out with every sense of equity, and responsibility. It argued that development should be evenly distributed in the state.
\end{abstract}

Keywords: Democracy, development, infrastructural development, equity, justice, Anambra state

\section{Introduction}

Nigeria re-embraced democracy on May 29, 1999, following the relinquishing of military power by the General Abubakar Abdulsalam led junta to an elected government led by Chief Olusegun Obasanjo. This saw the beginning of a new era in Nigeria's democratic experience, which for the most part has brought with it a corresponding transformation in the different spheres of the society. For instance, the ranking of the country's economy as the largest in Africa was made possible by uninterrupted democratic dispensation in the country.

As Odo (2015) observed, democracy ensure that the rights of individuals and groups are safeguarded particularly as it relates to civic obligations and privileges. It presupposes the right or freedom of expression by the individual. When this is allowed under democracy, the government will be more accountable to the people as a matter of necessity. He further stated that people can insist on transparency in governance and that way make the leaders accountable to the people. This is not always the case in the Nigerian situation as instances of elected officials refusing to resign even in the face of glaring 
disproportionate abuse of office are common. Indeed, democracy is being consolidated in Nigeria and many African states. Igwe (2010) opined that democracy is accepted the world over as a refined system of government that places high premium on human personality and rule of law. It is because of the role which democracy plays in development and modernization that scholars and public commentators clamour for its enthronement as the best leadership option to move a society forward (Igwe, 2010).

The focus of this paper is to examine the role of democracy in the infrastructural development of Anambra state, with particular emphasis on Anambra West Local Government Area (LGA). Anambra West LGA could probably be argued as one of the least developed LGAs among its peers in the state. It is at the fringe of the state and has boundary with communities in Kogi state. Access to the area is not only difficult but almost impossible during the rainy season. There is little or no serious effort made in the past to adequately accommodate the infrastructural developmental needs of the people of the area. According to Attah (2014) in this age of globalization and technological innovations, some communities still exist as in the Stone Age era where all the modern amenities of life are absent and citizens rely on nature and human natural instincts to survive. Nzam Community, the headquarters of Anambra West Local Government, Anambra State fits into the above description. A land so blessed with rich agricultural produce but yet wallows under the throes of underdevelopment and government neglect. Conversely, this area is responsible for the production of large quantity of the agricultural produce cultivated in the state. Petrol was found in commercial quantity in the area which resulted in the establishment of Orient petroleum industry in the place. It becomes necessary that a place like this should not be left behind in terms of provision of infrastructural facilities needed to open it up.

Recently succour came to the people of the area following the flagging off of construction of roads and bridges leading to the communities. According to Ilozue (2015), in line with the policy of opening up roads leading to the food basket and agrarian communities in the hinterland of the state, Anambra State Government has embarked on construction of a 200-metre bridge in addition to several road projects in Anambra East and Anambra West local government areas. He continued that flagging off the second phase of the about 11kilometre Umueze Anam, Mmiata and Nzam road with a major bridge would cost the government a total sum of N10 billion on the projects, which would be completed in three years. According to Ilozue (2015), the governor stated that the road is of strategic importance as it traverses major food-producing communities and farm settlements, and when completed, would boost socioeconomic activities in the area. Several other projects like electricity supply for Mmiata Anam were commissioned.

There were also other projects undertaken by this administration and some of them were already completed. It is necessary to state at this juncture that the communities and local government areas where these projects were undertaken were totally neglected by previous administrations. The increase in 
developmental projects in the area is not unconnected to the fact that somebody from the area was given opportunity to man the topmost political post in the state. Being from the area and having known the difficulties the areas have been experiencing, the incumbent governor then embarked on massive infrastructural development of the area. It could then be seen at least from the face value that democracy is obviously playing a very vital role in the infrastructural development of the area especially Anambra west local government area. It is against this background that role of democracy in the development of the area could be justified. In view of the above, this paper is focused on answering the following questions;

i. How do the people of Anambra West local government area perceive democracy as a system of government?

ii. What roles can democracy play in the development of Anambra West local government area?

iii. How can democratic government in the state be improved to meet the needs of the people of the Anambra West local government area?

\section{Literature Review}

Relevant literatures were reviewed in line with the objectives of the paper as outlined in the few research questions.

\section{Democracy Defined}

According to Kendall, Murray and Linden (2004), a democracy is a political system in which the people hold the ruling power either directly or through elected representatives. According to the authors, democracy can be participatory or representative in nature. In most democratic countries, people have a voice in the government through representative democracy. In a representative democracy, elected people are supposed to convey the concerns and interests of those they represent. The government formed in this manner is expected to be responsive to the wishes and aspirations of the people. Elected persons are held responsible through elections (Kendall et al., 2004). This is also the case in Nigeria. Following the improvement in the electioneering processes in the country, it is now possible than ever before for people to hold their elected representatives accountable. This certainly will make the elected individuals to be up and doing as representatives of the people. It could be argued that true democracy has the tendency of bringing development to the people. This is possible when voters have the right and are allowed to use their ballots to remove a non responsible and performing government. This brings us to the other key concept of the study which is development.

\section{What is Development?}

Development connotes several meanings to different people at different points in time. However, for the purpose of this paper, development will be seen from the infrastructural points of view. Development in the economic sense could be seen as growth in the economic indicators of a nation. For instance, Todaro 
(1979) saw development as the capacity of a national economy, whose initial economic conditions have been more static, to generate and sustain an annual increase in its Gross National Product (GNP) at rate of 5 or $7 \%$. This definition is purely economic in orientation. The pitfalls of economic development are numerous since not everybody seems to benefit directly from it. For instance, the rebranding of Nigeria as the largest economy in Africa does not make it better than some African countries where the governments are more responsible to the citizens. As earlier stated in this paper, development will be seen from the angle of improvement in infrastructures in the society. The concept of infrastructural development entails the building of basic facilities in the society. Some of which include good road networks, steady power supply, building and equipping of schools to meet the required minimum standards, building of hospitals and health centres to cater for the health needs of the people etc. Oyedele (2012) stressed that infrastructure development is the basis of measuring the performance of democratic leaders and it is the foundation of good democratic governance. Infrastructural development also leads to economic development and vice versa. The concept of development in this paper is therefore seen principally from this view point.

\section{Peoples' Perception of Democratic Governance in Nigeria}

It is not possible for everybody in the country to hold same view on this matter. It is possible however, that people will differ in the manner in which they perceive democratic system of government in the country. For instance, Jamo (2013: 85) argued that;

Everyone expected the return of Nigeria to democratic rule will bring about development. On the contrary Nigeria is still left behind in this sphere of human development. This has made many people still hold doubts on whether development is achievable under the present democratic dispensation due to growing insecurity, poverty, corruption and unemployment to mention but a few despite growing revenue.

Nigerian democratic experiment so far has not yielded the needed change it was expected to do. In a similar development, Ojakorotu (2009) stated that since the beginning of the present democratic dispensation, it seems that many are wondering how the governments have addressed basic national and personal economic problems in the country with poverty still very much prevalent. Incidentally, performance of politicians within the period is being questioned over their role in improving the welfare of citizens, and a consequent low rating of performance of democracy. The question is, is democracy neglectful of citizens' welfare in Nigeria? The present democratic dispensation has failed in many respects. It appears that virtually all the indicators for measuring developmental strides in a nation have shown any positive progress since the return of the country to democratic governance. One of the reasons adduced by the people at the hem of affairs in the country for the 
little or no successes recorded under this era is that the prolonged military rules in the country bastardized the economy terribly.

It is on record that the country generated more revenue under the present democratic dispensation than under the military era still there is little or nothing to show for it. It is obvious that corruption and mismanagement of funds and resources were responsible for the failure of the political class to turn around the fortunes of the country. It was alleged that over 16 billion US dollars was spent on power generation under President Obasanjo's regime. In spite of this, power supply in the country become more epileptic than it used to be. There was also the story of trillions of Naira spent on subsidy for petroleum products which could not be accounted for under President Jonathan's government. At a point during the same regime, the then governor of central bank of Nigeria Lamido Sanusi alleged that almost 50 billion dollars could not be accounted for. When elected political office holders are not transparent and accountable to the people, then the basic tenets of democracy which is hinged on accountability, transparency, rule of law and being responsible to the people may not be achieved.

Democracy as a system of government is supposed to be seen as the hope of the people owing largely to the fact that it is government of the people, by the people and for the people. In the Nigerian situation, it has become government of the elected representatives of the people, by the representatives of the people and for the representatives of the people. This accounts for why politician are often willing to do anything humanly possible to clinch (steal) political power and also to retain it at all cost. In the context of this paper, the author tried to examine people's perception of democracy in Anambra West local government area of Anambra state. This is with a view to ascertaining the manner in which inhabitants of the area perceive democratic governance in the state vis a vis the election of somebody from their area as the governor of the state.

\section{Roles of Democracy in the Development of Nigeria}

There is a divided opinion on the roles of democracy in development. Considerable number of scholars including (Pel, 1999; Campos, 1994; Jamo, 2010) cited in Jamo (2013) maintained the view that, there is causal link between democracy and development, while others including Sirowy and Linkels (1991), Bardhan (2002), Przeworski and Lamongi (2007) cited in (Jamo, 2013) on the contrary maintained the opposite view. It is necessary to state that growing theoretical literature is replete with optimism on the relationship between democracy and improvement of the quality of life of citizens (Diamond, 2005; Gyimah-Boadi, 2004) cited in (Ojakorotu, 2009). Ironically, a corresponding volume of empirical literature is skeptical of the reality of this relationship in most of Africa (Ake, 1996; Sindzing, 2006; Carter and Stokes, 2002; Ufo and Fidelis, 2005; Drung, Kriechaus and Luztig, 2006) cited in (Ojakorotu, 2009). This thinking has been explained in terms of failure of Eurocentric development paradigm to address problems of human 
advancement within the context of parallel liberal democracy for most of Africa and the third world (Ake, 1996) cited in (Ojakorotu, 2009).

Chan (2009) cited in Jamo (2013) examined whether developing countries need to adopt democracy or western model to achieve economic success. The study argues that, economic and social freedom is necessary, but not western style institution or culture. This study argues that liberal democracy is not a prerequisite to development, what is important for development is social and economic rights rather than the western ideology. Development can be achieved irrespective of the type of regime, insofar as social and economic freedom is available (Jamo, 2013). This study could be adopted to explain the event in Nigeria in the recent past. It is on record that the different military regimes that existed in the past in the country were responsible for putting in place several infrastructural development that are still in existence today for instance, the refineries, railways, schools, hospitals etc.

What was actually lacking was the so much acclaimed freedom that characterizes democratic governance. The military regimes were blamed for being corrupt; however, the present democratic dispensation (1999 to date) could not be absolved of corruption. It was alleged that a quarter of the total revenue accruable to the country goes to the National Assembly. If this assertion is a factual one, then one can rightly say that corruption is very much in existence under democratic rule in Nigeria. There were noticeable improvements in the economic indicators in the country which eventually led to the rebranding of the nation as largest economy in Africa. This however, does not change the poverty rate in the country nor does it reduce the rate of unemployment which has become worst since the country adopted democratic form of government. It is in this view that Jamo (2013: 93) stressed that:

Democracy is among the most popular system of government globally because of the expectation that it facilitates development due to the possession of instruments that support development. However, reality in Nigeria using different indicators revealed that, democracy in the short run did not improve development, rather contradicted our earlier notion that there is causal relationship between democracy and development. This study also coincided with other previous findings that, though democracy is important for development, but it is not a prerequisite for development.

The researchers observed after several visits to Anambra West local government that the area was lacking in vital infrastructural facilities. For instance, due to the nonexistence of tarred roads in the area, it was practically impossible to get to most communities in the area by road especially during the raining season. The researchers further observed that there was no power supply, no functioning health institutions and absence of properly built and equipped schools etc. It appears the situation has started changing since the inception of the new administration in the state. The state government is 
working towards providing the needed infrastructural facilities to the area (Ilozue, 2015). It therefore follows that democracy can plays vital roles in the infrastructural development of the area.

\section{Ways of improving Democratic Governance in Nigeria}

Governance in Nigeria can be improved with a view to engendering economic growth and infrastructural development. However, these are not the only successes deemed possible when there is improvement in governance. The emphasis on the two is in tandem with the focus of this paper. One of the ways of improving democratic governance in Nigeria is by having credible elections. If it is possible to remove a non performing government using the almighty ballots during election, then people elected into positions of authority will have no choice but to seat up and perform creditably. That is why Ikezue (2014) stated that political office holder whether elected or appointed should be accountable to the people. Leaders must lead by example and maintain the highest level of transparency in the discharge of their duties. Prosecution and conviction of corrupt officials is necessary to forestall increasing incidences of corruption. In this regard, the anti-corruption agencies must live up to the expectation of the people and bring to book corrupt officials whose actions or inactions have contributed to the seemingly experienced lack of transparency and accountability in governance (Ikezue, 2014). The anticorruption agencies should be effective and should be allowed to carry out their legally assigned mandate. If the agencies are not effective, they should be scrapped and replaced with more effective and result yielding ones. There should be equity in the distribution of resources and allocation of funds. Prudence in management of funds should not only be imbibed by political office holders but must be maintained and sustained. Equity should equally be maintained in zoning of political positions among the constituent units so that no section of a state or the nation will fill marginalized.

\section{Theoretical Framework}

This paper adopted the pluralist model which is rooted in functionalist perspective. It assumes that people share a consensus on central concerns, such as freedom and protection from harm, and that government serves important functions in society that no other institution can fulfil (Kendall et al., 2004). This perspective was originally founded by de Tocqueville (1945, first published, 1835). He believed that democracy would become unworkable if one division in society came to dominate all others. Such a situation could lead to a tyranny of the majority: one group in society would be in permanent majority and the interests and wishes of the minority could be totally disregarded (Haralambos and Holborn, 2004). Functionalists suggest that divergent viewpoints lead to a system of political pluralism in which the government functions as an arbiter between the competing interests and viewpoints. According to the pluralist model, power in political systems is 
widely dispersed throughout many competing groups (Dahl, 1961) cited in (Kendall et al., 2004).

From a pluralist perspective, representative democracy (coupled with the checks and balances provided by the legal system, and the division of governmental powers between a central government and smaller units such as provinces and municipalities) ensures that no one group can overpower the others and that individual rights are protected (Kendall et al., 2004). This theory could be adopted in explaining the democratic experience in Anambra state in particular and Nigeria in general. Government serves important functions in the society by; maintaining law and order, planning and directing society, meeting social needs and handling international relations, including warfare (Kendall et al., 2004). It is against this assertion that one can argue that democracy has a role to play in the society. In the context of this paper, the author attempted to associate democratic governance in Anambra state with infrastructural development of Anambra West local government area. This is consequent upon the emergence of a democratic dispensation which has taken upon itself the desire to see to some of the infrastructural needs of the people in Anambra West local government area. It is therefore a truism that democracy as conceptualized in this paper could be a portent tool for development in human society.

\section{Methodology}

This paper adopted the cross sectional survey method and also the mixed method of data collection. This involves the use of structured questionnaire and in depth interviews as instruments for data collection. A sample size of 400 respondents was chosen for the administration of the quantitative instrument using Yamane's sample size determination formula. The administration of the quantitative instrument (questionnaire) was done by the researcher and three research assistants trained for two days on the methodology and objectives of the study. The respondents for the quantitative data were chosen by the application of multi stage sampling procedure which is a combination of several sampling techniques. The LGA was clustered into wards. There are 10 wards in Anambra West LGA. Through the application of the balloting method of the random sampling technique, four wards were selected.

They are Nzam, Umueze Anam, Umuoba Anam and Oroma Etiti. The researcher then applied the systematic sampling technique for selecting the respondents to the study. However, three communities in the LGA were chosen for the in depth interviews. The communities are Nzam, Oroma Etiti and Olumbanasa Ode. These communities were chosen because of the ease of accessing them owing largely due to the poor road networks in the area. In these communities, six (6) participants were purposively selected for the in depth interview. These are men and women opinion leaders whose wealth and depth of experience enriched and strengthened the quantitative data. A male and a female in depth interview participants were chosen from each of the three communities. The quantitative data collected in the study were analysed using 
the frequency distribution tables showing frequency counts and percentages. However, the qualitative data were transcribed and analyzed using the narrative method of content analysis.

\section{Data Presentation and Analysis}

Collated data were shown in frequency distribution tables showing the frequency counts and percentages. 
Table 1: Socio-Demographic Characteristics of Respondents

\begin{tabular}{|c|c|c|}
\hline Variable & Frequency & Percent \\
\hline \multicolumn{3}{|l|}{ Gender } \\
\hline Male & 198 & 51.2 \\
\hline Female & 189 & 48.8 \\
\hline Total & 387 & 100.0 \\
\hline $\begin{array}{l}\text { Age } \\
23-32\end{array}$ & 28 & 7.2 \\
\hline $33-42$ & 122 & 31.5 \\
\hline $43-52$ & 122 & 31.5 \\
\hline $53-62$ & 100 & 25.8 \\
\hline $63-72$ & 10 & 2.6 \\
\hline 73 and above & 5 & 1.3 \\
\hline Total & 387 & 100.0 \\
\hline $\begin{array}{l}\text { Marital Status } \\
\text { Single }\end{array}$ & 58 & 15.0 \\
\hline Married & 275 & 71.1 \\
\hline Divorced & 34 & 8.8 \\
\hline Separated & 5 & 1.3 \\
\hline Widowed & 15 & 3.9 \\
\hline Total & 387 & 100.0 \\
\hline $\begin{array}{l}\text { Level of Education } \\
\text { No formal education }\end{array}$ & 39 & 10.1 \\
\hline Primary education & 106 & 27.4 \\
\hline Secondary education & 110 & 28.4 \\
\hline Tertiary education & 132 & 34.1 \\
\hline Total & 387 & 100.0 \\
\hline $\begin{array}{l}\text { Occupation } \\
\text { Farmer }\end{array}$ & 173 & 44.7 \\
\hline Trader & 41 & 10.6 \\
\hline Artisan & 105 & 27.1 \\
\hline Civil servant & 54 & 14.0 \\
\hline Driver & 14 & 3.6 \\
\hline Total & 387 & 100.0 \\
\hline $\begin{array}{l}\text { Religious Affiliation } \\
\text { Christianity }\end{array}$ & 321 & 82.9 \\
\hline Islam & 8 & 2.1 \\
\hline $\begin{array}{l}\text { African Traditional } \\
\text { Religion }\end{array}$ & 58 & 15.0 \\
\hline Total & 387 & 100.0 \\
\hline
\end{tabular}

Table 1 shows that there were more males than females in the distribution. The males constituted $(51.2 \%)$ of the total population while the females made up the remaining (48.8\%) of the population. Age distribution of the respondents had a mean age of 45.7 years, a standard error of mean of .495; a median age of 45 years and a modal age of 54 . The distribution also had a standard deviation of 9.728 , a minimum age of 23 years and a maximum age of 76 years. Table 1 also indicates that $(31.5 \%)$ of the respondents were $33-42$ and $43-52$ years 
respectively. Only $(1.3 \%)$ of the respondents were 73 years and above. The implication of this is that the distribution had more respondents who were 3362 years old. The table also showed that $(71.1 \%)$ of the respondents were married while $(1.3 \%)$ of them were separated. This implied that there were more married persons in the distribution.

Table 1 shows that $(34.1 \%)$ of the respondents had tertiary education while $(10.1 \%)$ of them had not got any formal education. This indicates that there were more literate people in the distribution. In Table 1 also, $44.7 \%$ of the respondents were farmers while $3.6 \%$ of them were drivers. This shows that there were more farmers in the distribution. This is however expected since farming is one of the major occupations of the people in Anambra West LGA. Table 1 also shows that $82.9 \%$ of the respondents were Christians while $2.1 \%$ of them were Moslems. This means that more than three quarters of the respondents were Christians. This is not unexpected because the study area is predominantly dominated by Christians.

Table 2: Respondents' views on whether or not democratic form of government is better than other forms of government

\begin{tabular}{lrr}
\hline Response & Frequency & Total \\
\hline Yes & 333 & 86.0 \\
No & 54 & 14.0 \\
\hline Total & 387 & 100.0 \\
\hline
\end{tabular}

Table 2 shows that most the respondents $(86 \%)$ were of the views that democracy is the best form of government. However, $14 \%$ of the respondents did not see democracy as the best form of government.

Table 3: Respondents' perception on the present democratic dispensation in Anambra state

\begin{tabular}{lrr}
\hline Response & Frequency & Total \\
\hline It is the best form of government & 41 & 10.6 \\
It is people oriented & 101 & 26.1 \\
It provides the basic infrastructural needs of the people & 193 & 49.9 \\
It is just a form of government & 52 & 13.4 \\
\hline Total & 387 & 100.0 \\
\hline
\end{tabular}

As shown in Table 3, 49.9\% of the respondents stressed that the present democratic dispensation in the state provided the basic infrastructural needs of the people while $(10.6 \%)$ of them maintained that it is the best system of government. Participants in the in depth interview did not differ significantly from the above. One of the participants in the interview who is a 65 year old male opinion leader from Nzam stated that "democracy is the best form of government that I know. It is better than the military rule and it has come to 
stay in this country". Another participant in the interview who is a 62 year old female opinion leader from Nzam stressed that;

Democracy has remained the best form of government everywhere and will remain so for a very long to come. We can now decide who will rule or not rule us. This is the desire of our people, to have a government that will listen to us because we voted for them to come into power. When they fail to deliver their promises, we have the right to vote them out of power.

Table 4: Respondents' views on the roles played by the present democratic dispensation in the state

\begin{tabular}{lrr}
\hline Response & Frequency & Percent \\
\hline $\begin{array}{l}\text { This democratic dispensation has provided some of the } \\
\text { needed infrastructural development in the area }\end{array}$ & 231 & 59.7 \\
$\begin{array}{l}\text { It has carried the people in area along in its policies and } \\
\text { programmes }\end{array}$ & 43 & 11.1 \\
$\begin{array}{l}\text { This democratic dispensation has guarantee equitable } \\
\text { distribution of power among the constituting units in the state }\end{array}$ & 61 & 15.8 \\
$\begin{array}{l}\text { It has allowed for the equity in the distribution of the } \\
\text { resources in the state }\end{array}$ & 52 & 13.4 \\
\hline Total & 387 & 100.0 \\
\hline
\end{tabular}

It is shown in Table 4 that $59.7 \%$ of the respondents were of the opinion that the democratic dispensation had provided some of the needed infrastructural development in the area while $(11.1 \%)$ of them maintained that it had carried the people along in its policies and programmes. The in depth interview participants were of the views that the present democratic dispensation in the state has played a vital role in their area. One of the participants in the interview, a 58 year old male opinion leader from Oroma Etiti commented;

The present democratic government in the state has done so much for the area. Most communities in this area do not have power supply before the advent of this dispensation. This has changed remarkably because we now enjoy noticeable improvement in power supply and the bad roads are now being reconstructed. This is indeed a positive development for us.

Another participant in the in depth interview who is a 55 year old female opinion leader from Oroma Etiti said;

This government has done so much for this area. This is as a result of the efforts of the government in providing access road and other basic amenities such as hospitals, electricity and renovation of dilapidated structures in the primary and secondary schools in the area. The health centres have become useful again 
because our people now safely go there for treatment and for other medical needs.

Table 5: Respondents' views on whether or not there is need for improvement in the present democratic dispensation

\begin{tabular}{lrr}
\hline Response & Frequency & Percent \\
\hline Yes & 295 & 76.2 \\
No & 92 & 23.8 \\
\hline Total & 387 & 100.0 \\
\hline
\end{tabular}

An overwhelming majority of the respondents (76.2\%) stressed that there is need for improvement in the present democratic dispensation while $(23.8 \%)$ of the said there is no need for improvement. All the participants stated that there is need for improvement in the activities of government in the area.

Table 6: Respondents' views on how to improve the present democratic dispensation in the state

\begin{tabular}{lrr}
\hline Response & Frequency & Percent \\
\hline $\begin{array}{l}\text { By implementing more people oriented programmes } \\
\text { By maintaining equity in the distribution of power and }\end{array}$ & 97 & 25.1 \\
$\begin{array}{l}\text { resources } \\
\begin{array}{l}\text { By providing the needed infrastructures to the areas they are } \\
\text { needed }\end{array}\end{array}$ & 81 & 20.9 \\
$\begin{array}{l}\text { By creation of employment opportunities and skill } \\
\text { acquisition centres }\end{array}$ & 92 & 23.8 \\
\hline Total & 387 & 100.0 \\
\hline
\end{tabular}

In Table 6, (30.2\%) of the respondents maintained that the present democratic dispensation in the state can be improved by providing the needed infrastructures to the areas they are needed while (20.9\%) of them said it is by maintaining equity in the distribution of power and resources. Participants in the in depth interview were of the views that the dispensation can be improved for better performance. For instance, one of the participants in the interview who is 65 year old male opinion leader from Nzam said that the present democratic dispensation in the state can be improve by;

Intensifying efforts in providing the basic amenities needed in area which will make life meaningful for the people in this area. Loans could be given to farmers to increase their productive capabilities since the major occupation of the people is farmer. Fertilizers and other agricultural inputs should also be provided to alleviate the plight of the masses which will enable them to cultivate more farm produce and earn more money in the process. 
Another participant in the in depth interview, a 67 year old male opinion leader from Olumbanasa Ode stated;

Government must carry everybody along if it is to succeed. It is very necessary to maintain equity and fairness in the distribution of resources in the state. Prudent management of resources is very necessary and creating enabling environment for progress in the society will assist the government improve a lot. Then finally, people should demand for good governance when and where it appears the reverse is the case.

\section{Discussion of Findings}

It was found that democratic government is the best form of government, people oriented, and largely provides the basic infrastructural needs of the people. These findings are consistent with responses from in depth interviews. It was found from the interviews that democracy is the better than military rule and has come to stay in the country. It was also found that people desire to have a government that will listen to them because the people voted for the government to come into power and can vote them out of power if they fail to deliver. These findings were supported by Igwe (2010) and Odo (2015) who had argued that democracy provides rights to groups and individuals and it is accepted the world over as a refined system of government as it places much premium on human personality and rule of law. It is because of the role which democracy plays in development and modernization that scholars and public commentators clamour for its enthronement as the best leadership option to move a society forward (Igwe, 2010).

However, these findings were not supported by Ojakorotu (2009) and Jamo (2013) who had earlier stated that Nigerians were skeptical on whether or not the present democratic experience could foster the needed development in the country. The findings however are consistent with the postulations of the pluralist model on power which assumes that government serves important functions in the society by; maintaining law and order, planning and directing society, meeting social needs and handling international relations, including warfare (Kendall et al., 2004). The findings also agree with the pluralist postulations that representative democracy (coupled with the checks and balances provided by the legal system, and the division of governmental powers between a central government and smaller units such as provinces and municipalities) ensures that no one group can overpower the others and that individual rights are protected (Kendall et al., 2004).

This paper found that several roles were played by the present democratic dispensation in the state. These roles include provision of needed infrastructural development in the area, carrying people along in its policies and programmes, guaranteeing of equitable distribution of power among the constituting units in the state and maintenance of equity in the distribution of the resources in the state. These findings corroborate the ones from the in depth interviews. It was found that the present democratic dispensation has provided 
some of the needed infrastructural amenities such as improvement in power supply, making the hospitals functional, renovation of schools and reconstruction of roads. The above findings are consistent with Igwe (2010) and Odo (2015) where they argued that democracy has the potentials of leading the nation to greater height if it is properly practiced.

Finally, it was found in this paper that the present democratic dispensation in the state can be improved by implementing people oriented programmes, maintaining of equity in the distribution of power and resources, provision of needed infrastructure to the area they are most needed and by the creation of employment opportunities and skill acquisition centres. These findings agreed with the ones from the in depth interviews. It was found from the interviews that government should intensify efforts in providing the basic amenities needed in the area and making agricultural inputs available to farmers. The study also found the need for government to be prudent in the management of resources, creation of enabling environment and that people should demand for good governance as a matter of right. These findings are supported by Ikezue (2014) who stated that political office holder whether elected or appointed should be accountable to the people. Leaders must lead by example and maintain the highest level of transparency in the discharge of their duties. Prosecution and conviction of corrupt officials is necessary to forestall increasing incidences of corruption.

\section{Conclusion}

This paper examined the role of the present democratic dispensation in the development of Anambra West local government area. Emphasis was placed more on the infrastructural development which constituted one of the basic needs of the people of the area. Anambra West local government area was grossly marginalized in the past by successive governments whether military or civilian ones. However, things stated changing following the election of somebody from the area into the governorship position of the state. Since then, a lot of actions were taken towards making the place safe for habitation. It was therefore found that this democratic dispensation has played and is still playing a very vital role in the provision of the needed infrastructural development of the area.

\section{Recommendations}

In line with the findings of this paper, the following recommendations are made. The political class should play politics with every sense of responsibility, purposefulness, maintenance of equity, justice, transparency and sincerity. This is with the view to allowing sections of the state which had not participated in the leadership of the state to do so. This should be done bearing in mind that no part of the state should be left unattended to. This paper also recommended that development should be evenly distributed in the state in such a manner that every constituent unit will have a sense of belonging and usefulness in the political equation of the state. Areas that are least developed 
should be identified and carried along in the developmental efforts of the present democratic dispensation.

Finally, the paper recommends that the present democratic dispensation in the state can be improved by implementing people oriented programmes, maintaining of equity in the distribution of power and resources, provision of needed infrastructure to the area they are most needed and by the creation of employment opportunities and skill acquisition centres. The paper also recommended the need for government to be prudent in the management of resources, creation of enabling environment and that people should demand for good governance as a matter of right. This is with a view to challenging the excesses of a sitting government so that people's interest will always be considered.

\section{References}

Attah, A. (2014, February 9) Nzam: Anambra's most neglected community. The Sun Newspaper. Retrieved from http://sunnewsonline.com/new/nzamanambras-neglected-community/.

de Tocqueville, A. (1945, first published 1835) Democracy in America. Volume 1 Vintage, New York.

Haralambos, M., Holborn, M. \& Heald, R. (2004) Sociology: Themes and Perspectives 6th ed. London: HarperCollins.

Igwe, L.E. (2010) Democracy and development in Nigeria: Issues and challenges. International Journal of Economic Development Research and Investment, 1(2\&3): 116-122.

Ikezue, C.E. (2014) Governance and Security Challenges in Anambra State. Journal of Religion and Human Relations, 1(6): 159-170.

Ilozue, C. (2015, February 5) Anambra to spend $\mathbb{N} 10$ billion on roads, bridges. Daily Independent Newspapers. Retrieved from http://dailyindependentnig.com/2015/02/anambra-spend-n10b-roads-bridges/.

Jamo, I.A. (2013) Democracy and development in Nigeria: is there a link? Arabian Journal of Business and Management Review (OMAN Chapter), 3(3): 85-94.

Kendall, D., Murray, J.L. \& Linden, R. (2004) Sociology in Our Times, 3rd Canadian Edition, Canada: Thomson Wadsworth.

Odo, L.U. (2015) Democracy and Good Governance in Nigeria: Challenges and Prospects. Global Journal of Human-Social Science, 15(3).

Ojakorotu, V. (2009) From "Authoritarian Rule" to "Democracy" in Nigeria: Citizens' Welfare a Myth or Reality. Journal of Alternative Perspectives in the Social Sciences, 1(2): 152-192.

Oyedele, O.A. (2012) The Challenges of Infrastructural Development in Democratic Governance, Construction Economics and Management I.

Todaro, M.P. (1979) Economics for a Developing world. London: Longman Group Ltd. 